Article

\title{
Citric Acid Assisted Phytoremediation of Chromium through Sunflower Plants Irrigated with Tannery Wastewater
}

\author{
Ali Imran Mallhi ${ }^{1}$, Shahzad Ali Shahid Chatha ${ }^{2}{ }^{(0)}$, Abdullah Ijaz Hussain ${ }^{2}{ }^{(0)}$, \\ Muhammad Rizwan ${ }^{3}$ (D), Syed Asad Hussain Bukhar ${ }^{4}\left(\mathbb{D}\right.$, Afzal Hussain ${ }^{3,5}$, Zahid Imran Mallhi ${ }^{3}$,

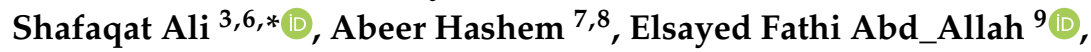 \\ Mohammed Nasser Alyemeni ${ }^{7}$ and Parvaiz Ahmad $7,10, *$ (D) \\ 1 Department of Applied Chemistry, Government College University Faisalabad, Faisalabad 38000, Pakistan; \\ imranmallhi72@gmail.com \\ 2 Department of Chemistry, Government College University Faisalabad, Faisalabad 38000, Pakistan; \\ Chatha222@gmail.com (S.A.S.C.); abdullahijaz@gcuf.edu.pk (A.I.H.) \\ 3 Department of Environmental Science and Engineering, Government College University Faisalabad, \\ Faisalabad 38000, Pakistan; mrazi1532@yahoo.com (M.R.); afzaalh345@gmail.com (A.H.); \\ zahid.mallhi@yahoo.com (Z.I.M.) \\ 4 Department of Agronomy, Bahauddin Zakariya University, Multan 60800, Pakistan; \\ asadbukhari@bzu.edu.pk \\ 5 Department of Environmental Sciences, The University of Lahore, Lahore 54000, Pakistan \\ 6 Department of Biological Sciences and Technology, China Medical University, Taichung 40402, Taiwan \\ 7 Botany and Microbiology Department, College of Science, King Saud University, P.O. Box. 2460, \\ Riyadh 11451, Saudi Arabia; habeer@ksu.edu.sa (A.H.); mnalyemeni@gmail.com (M.N.A.) \\ 8 Mycology and Plant Disease Survey Department, Plant Pathology Research Institute, ARC, Giza 12511, Egypt \\ 9 Plant Production Department, College of Food and Agricultural Sciences, King Saud University, \\ P.O. Box. 2460, Riyadh 11451, Saudi Arabia; eabdallah@ksu.edu.sa \\ 10 Department of Botany, S.P. College, Srinagar, Jammu and Kashmir 190001, India \\ * Correspondence: shafaqataligill@yahoo.com (S.A.); parvaizbot@yahoo.com (P.A.)
}

Received: 19 January 2020; Accepted: 4 March 2020; Published: 19 March 2020

\begin{abstract}
Heavy metals are rapidly polluting the environment as a result of growing industrialization and urbanization. The presence of high concentrations of chromium $(\mathrm{Cr})$, along with other pollutants, is widespread in tannery wastewater. In Pakistan, as a result of a severe shortage of irrigation water, farmers use tannery wastewater to grow various crops with a consequent decline in plants' yield. This experiment was performed to assess growth revival in sunflower plants irrigated with $0 \%$, $25 \%, 50 \%, 75 \%$, and $100 \%$ tannery wastewater, by foliar application of $0,2.5$, and $5.0 \mathrm{mM}$ citric acid (CA). The wastewater treatment curtailed biomass accumulation, the growth rate, and chlorophyll contents by exacerbating the oxidative stress in sunflowers. Foliar application of CA considerably alleviated the outcomes of $\mathrm{Cr}$ toxicity by curbing the $\mathrm{Cr}$ absorption and oxidative damage, leading to improvements in plant growth, biological yield, and chlorophyll contents. It is concluded that foliar application of CA can successfully mitigate the $\mathrm{Cr}$ toxicity in sunflower plants irrigated with tannery wastewater.
\end{abstract}

Keywords: chromium; wastewater; sunflower; biomass; chlorophyll contents

\section{Introduction}

Kasur, a city in Punjab Pakistan, is famous for tanneries. According to estimates, around 144,502 to 215,036 gallons of wastewater day ${ }^{-1}$ is discharged into the environment by 650 registered tanneries [1]. 
Tannery wastewater contains several organic and inorganic pollutants [2]. Farmers mostly use tannery wastewater in periurban areas due to a scarcity of irrigation water [3,4]. There are different heavy metals in tannery wastewater, such as $\mathrm{Cr}, \mathrm{Cd}, \mathrm{Mn}, \mathrm{Pb}, \mathrm{Fe}, \mathrm{Ni}$, and $\mathrm{Cu}$. Release of industrial effluent from tanneries is injurious for living organisms, including plants and animals [5]. The concentration of $\mathrm{Cr}$ in such water is considerably higher than other heavy metals [2]. Among heavy metals, chromium is ranked the 14th most noxious heavy metal globally; among different $\mathrm{Cr}$ oxidation states, $\mathrm{Cr}^{+6}$ is the most toxic because of the higher mobility/solubility and $\mathrm{Cr}^{+3}$ is the least toxic [6]. Plant growth and biomass is negatively affected through the application of industrial effluents. Outcomes of previous studies show that plant growth is negatively affected by $5 \mathrm{mg} \mathrm{L}^{-1} \mathrm{Cr}$ in the nutrient solution [7]. Application of chromium $\left(\mathrm{Cr}^{+6}\right)$ contaminated wastewater significantly reduced plant growth and photosynthesis in different crops, like maize, wheat, and sunflower, by causing oxidative stress [8-10]. The physiochemical processes of plants are badly affected by chromium stress [11]. Plant growth is reduced as a result of disruption in the photosynthetic process, damage to the ultrastructure of plant cells, oxidative stress such as electrolyte leakage (EL), hydrogen peroxide $\left(\mathrm{H}_{2} \mathrm{O}_{2}\right)$, malondialdehyde (MDA) and changes in miRNAs and proteins [8,12-15]. Sunflower is an oil seed crop in Pakistan and a key source of edible oil worldwide. As a hyperaccumulator plant, it can be grown under stressful conditions such as under heavy metal stress. Sunflower plants were cultivated on 82,000 hectares of land, producing 40,000 tons of oil during 2017-2018 (Pakistan Economic Survey 2017-2018). Though the sunflower plant is considered metal resistant, toxic concentrations of $\mathrm{Cr}$ may negatively influence its growth and development. The outcomes of the previous investigations have revealed that $\mathrm{Cr}$ stress induced oxidative damage to plants with a consequent decline in growth and yield [16]. As a result of limited resources and exorbitantly increasing population pressure, contamination of land and water bodies with heavy metals, especially $\mathrm{Cr}$, is a potential threat to food security and safety. The current situation demands an urgent remedy to ensure the provision of quality food to the population of Pakistan.

The beneficial effects of citric acid (CA) upon the uptake of $\mathrm{Cr}$ as well as in growth regulation in several plant species are well documented. The CA foliar application improved the germination rate and root weight of sunflower plant by improving the activities of several antioxidants enzymes including superoxide dismutase (SOD), catalase (CAT), peroxidase (POD) and ascorbate peroxidase (APX) [17]. Foliar application of CA, combined with 5-aminolevulinic acid (ALA), considerably increased the yield of sunflower plants. Citric acid spray on radish leaves reduced the uptake of $\mathrm{Cr}$ and its mobility [17]. Citric acid also increased the antioxidant enzyme activities, chlorophyll fluorescence, and reduced lipid peroxidation in Brassica napus [18]. Citric acid alleviated the $\mathrm{Cr}\left(\mathrm{Cr}^{+6}\right)$ toxicity by stimulating the antioxidant defense system in sunflower plants [19].

In the current study, it was hypothesized that CA may alleviate $\mathrm{Cr}$ toxicity in sunflower crop irrigated with tannery wastewater. Thus, the current study was designed to explore CA effects on morophogical, physiological, and chemical attributes of sunflower plants irrigated with tannery wastewater containing total $\mathrm{Cr}$ concentrations of $329 \mathrm{mg} \mathrm{L}^{-1}$.

\section{Results}

\subsection{Plants Growth and Biomass}

Growth features of sunflower plants under various treatments of tannery wastewater, along with application of CA, are presented in Figures 1 and 2. Findings revealed that increasing concentration of wastewater treatment progressively reduced the plant height, root length, number of leaves per plant, and the leaf area (Figure 1), along with the fresh and dry weight of root, shoot, and leaves of sunflower (Figure 2). The highest decrease in the abovementioned parameters was noticed upon $100 \%$ wastewater treatments. However, CA application remarkably improved all the studied agronomic traits, both under stressed and normal growth environments. The maximum ameliorative effect of CA was observed at $5.0 \mathrm{mM}$ foliar application treatment. 

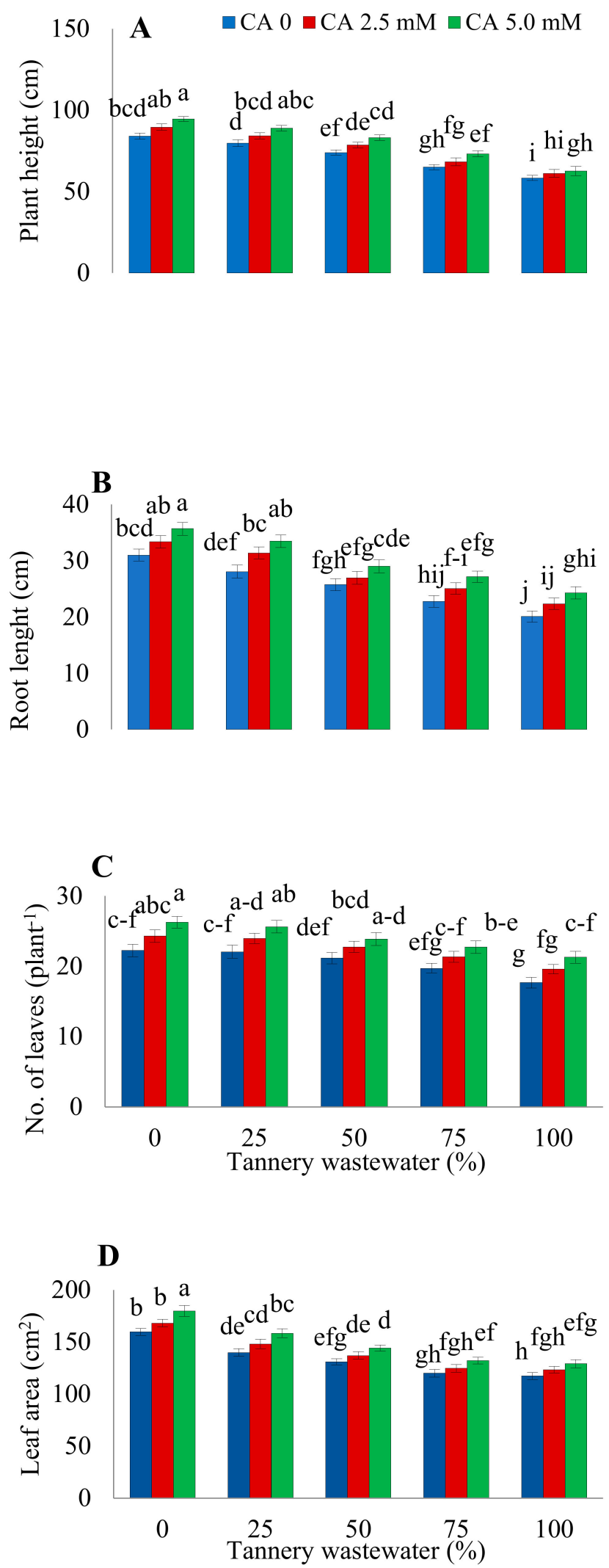

Figure 1. Impact of wastewater and citric acid (CA) on sunflower height (A), root lengths (B), number of leaves per plant (C), and leaf area (D) of sunflower plants. Data are means of 3 independent replicates, and different lettering indicates a significant difference among the values at $p<0.05$. 

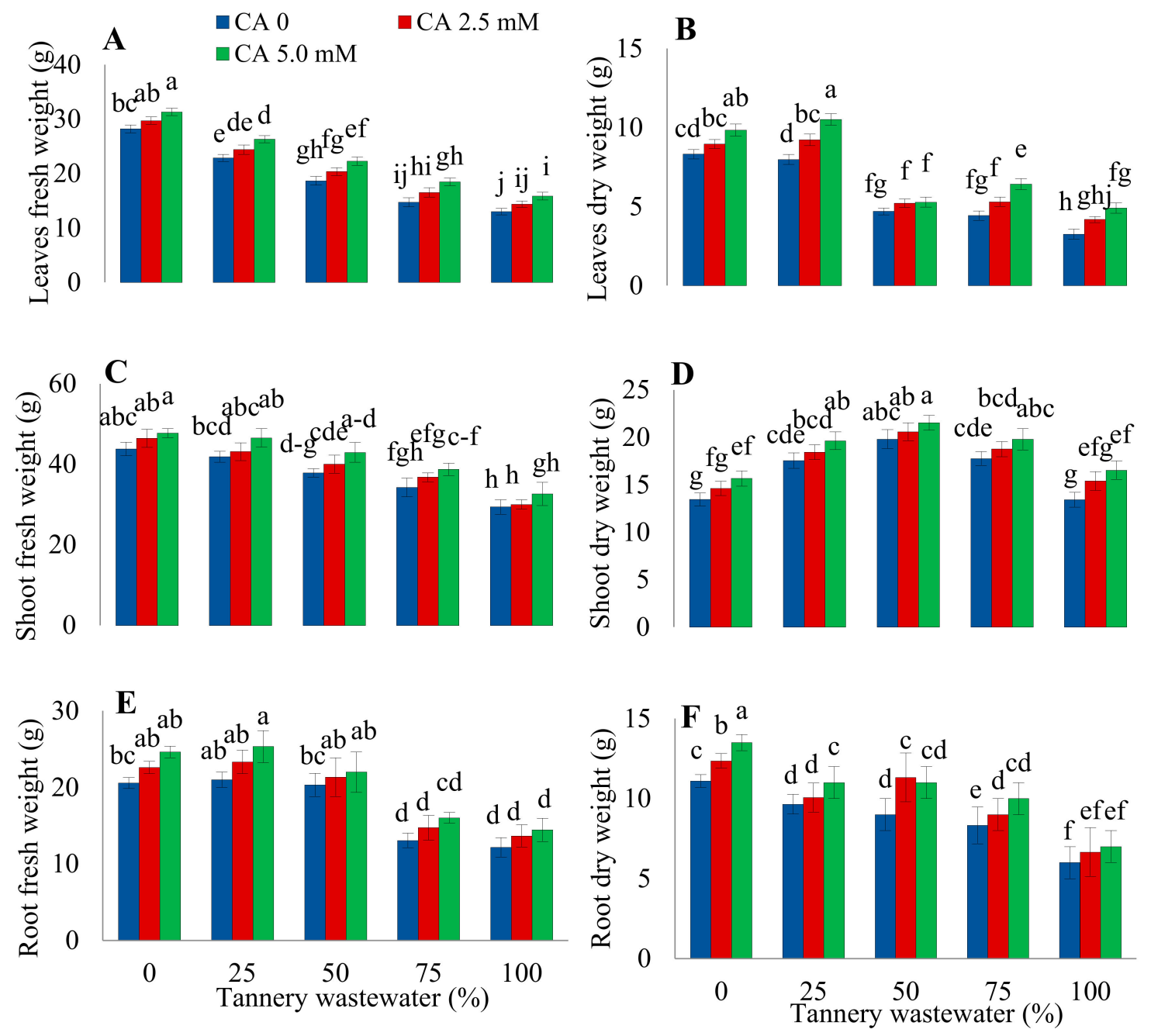

Figure 2. Impact of wastewater and citric acid (CA) treatments on leaf fresh weight (A), leaf dry weight (B), shoot fresh weight (C), shoot dry weight (D), root fresh weight (E) root dry weight (F) of sunflower plants. Data are means of 3 independent replicates, and different lettering indicates a significant difference among the values at $p<0.05$.

\subsection{Photosynthetic Pigments}

The application of wastewater severely decreased Chlorophyll $a, b$, and the total chlorophyll (Figure 3). Citric acid treatment significantly improved the pigment contents under $\mathrm{Cr}$ stress, as well as normal growth conditions. However, $5.0 \mathrm{mM}$ proved to be the most effective concentration of CA in mitigating the detrimental effects of wastewater on photosynthetic pigments.

\subsection{Oxidative Stress Parameters}

The presence of $\mathrm{Cr}$ in tannery effluent resulted in oxidative damage to sunflower plant (Figure 4). By increasing wastewater concentration, it sharply elevated the MDA concentration in the leaves and roots of sunflowers. The maximum value for MDA contents was recorded under $50 \%$ and $100 \%$ wastewater treatment in leaves and roots, respectively. Foliar treatment of CA significantly decreased the lipid peroxidation as revealed by reduced MDA content in plants. The most conspicuous decline in MDA content was detected in plants as compared to respective control plants under a $75 \%$ and $100 \%$ wastewater treatment along with a $5.0 \mathrm{mM} \mathrm{CA}$ application in leaves and roots, respectively. 

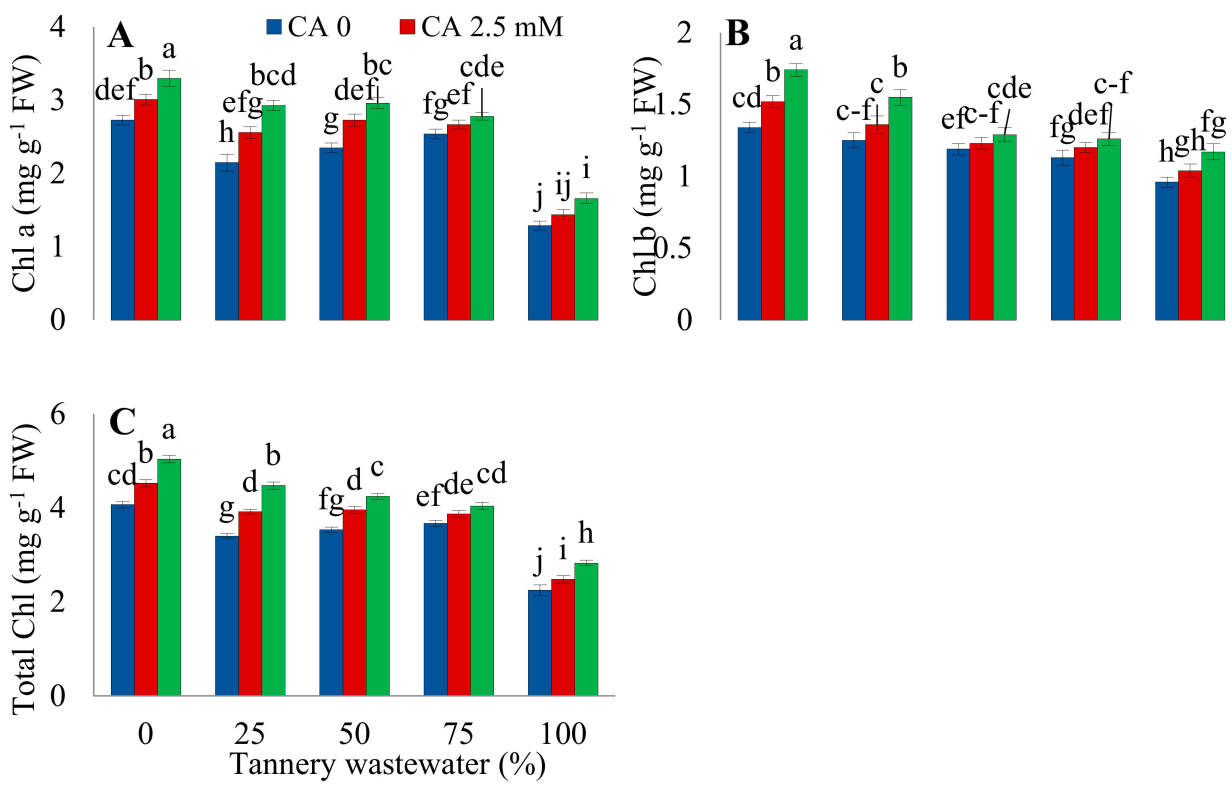

Figure 3. Impact of wastewater and citric acid (CA) treatment on chlorophyll a (A), chlorophyll b (B), and total chlorophyll $(\mathbf{C})$ of sunflower plants. Data are means of 3 independent replicates and different lettering indicates a significant difference among values at $p<0.05$.
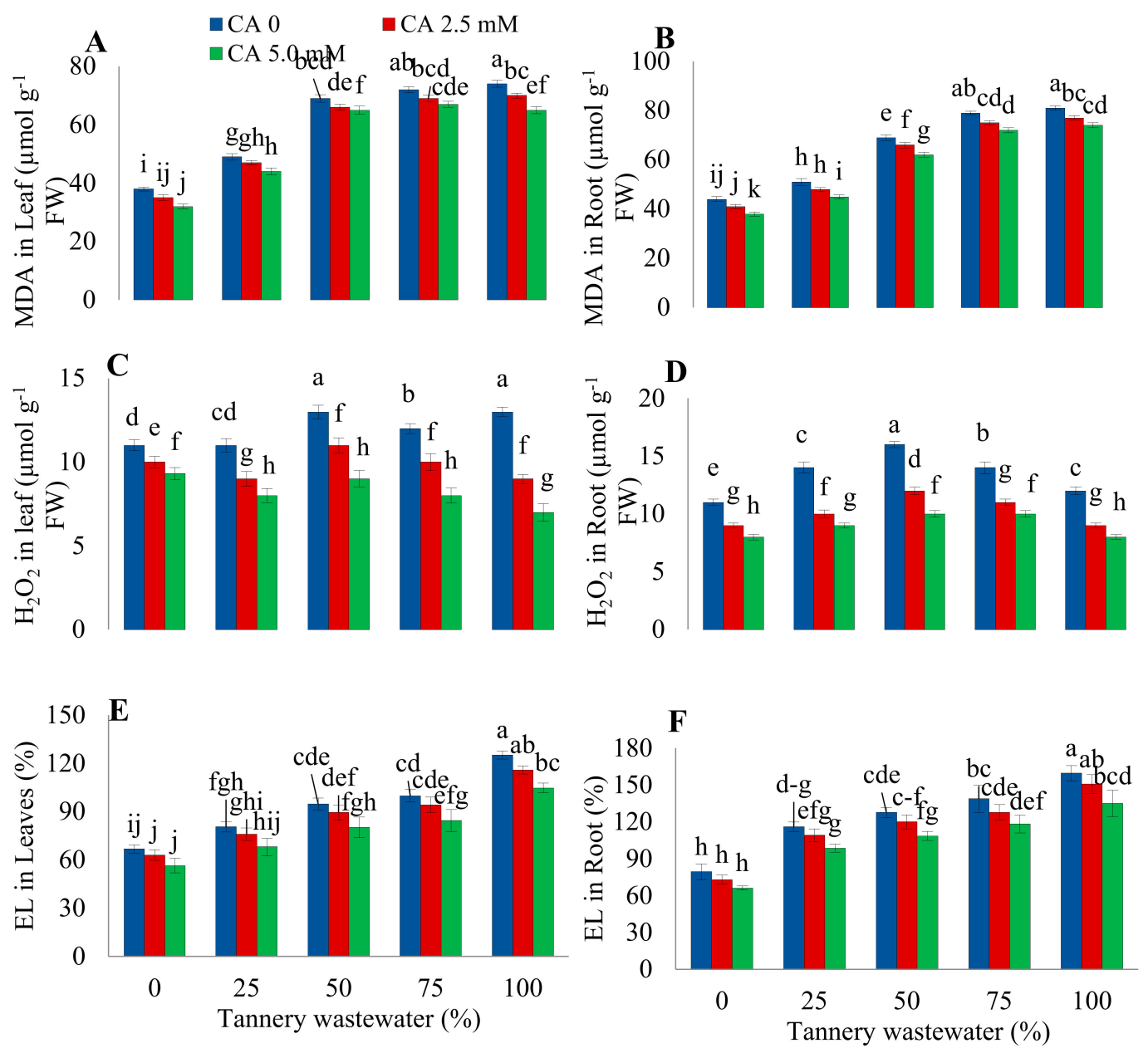

Figure 4. Impact of wastewater and citric acid (CA) treatment on leaf malondialdehyde (MDA) (A), roots MDA (B), leaves $\mathrm{H}_{2} \mathrm{O}_{2}(\mathbf{C})$, root $\mathrm{H}_{2} \mathrm{O}_{2}(\mathbf{D})$, leaf electrolyte leakage (EL) (E), and root EL (F) 
of sunflower plants. Data are means of 3 independent replicates, and different lettering indicates a significant difference among the values at $p<0.05$.

Similarly, wastewater treatment also caused oxidative damage by enhancing production of $\mathrm{H}_{2} \mathrm{O}_{2}$ in roots and leaves of plants, with the most pronounced effect at $50 \%$ wastewater application. Citric acid noticeably alleviated the oxidative damage to plants by decreasing $\mathrm{H}_{2} \mathrm{O}_{2}$ content both in the roots and leaves. The highest ameliorative effect was found in the plants irrigated with a $50 \%$ wastewater treatment in combination with a foliar application of $5.0 \mathrm{mM} \mathrm{CA}$. Electrolyte leakage also exhibited a proportional rise with an increasing concentration of wastewater treatment, both in the leaves and roots of plants. Nonetheless, $5.0 \mathrm{mM} \mathrm{CA}$ considerably mitigated the consequences of stress as depicted by the reduction in EL in both parts of the plants.

\subsection{Antioxidant Enzymes}

Activities of SOD were increased with the $25 \%$ wastewater treatment and decreased thereafter with a further increase in stress level, both in the leaves and root of plants. The CA treatment enhanced SOD activities in sunflower leaves irrigated with normal tap water. Application of $2.5 \mathrm{mM}$ CA enhanced the SOD activities, while $5.0 \mathrm{mM}$ CA declined the SOD activities in sunflower plants irrigated with $25 \%-50 \%$ wastewater (Figure 5). Foliar applied CA notably improved leaf SOD activity under a $75 \%-100 \%$ wastewater application. In comparison with control plants, the SOD activities in roots increased considerably with a $25 \%-50 \%$ wastewater treatment, showing a consequent decline with a further increase in stress level. Citric acid application enhanced SOD activities in sunflower roots, with the highest improvement being observed in the control and 100\% wastewater application supplemented with $2.5 \mathrm{mM}$ and $5.0 \mathrm{mM}$ CA treatment, respectively.

Mild to moderate levels ( $25 \%-50 \%)$ of wastewater treatment significantly decreased, while higher concentrations (75\%-100\%) increased the activities of POD in sunflower leaves. Application of CA significantly increased POD activities in sunflower leaves with a substantial surge at $100 \%$ wastewater irrigation, as compared with stress treatment alone. In roots, the activities POD increased with a $25 \%$ wastewater treatment and decreased with the increasing wastewater concentration. Citric acid application prominently improved the activities of POD in roots of sunflowers with the applied stress of tannery wastewater, in comparison with the stressed plants without CA treatment.

Wastewater treatment increased CAT activities at mild stress levels $(25 \%)$ with a subsequent decreasing trend, both in the leaves and roots. However, CA supplementation further enhanced CAT activities in normal, as well as stressed plants in both plant parts. The effect of $5.0 \mathrm{mMCA}$ concentration was the most prominent in improving CAT activities. Activities of APX were increased with a $25 \%-50 \%$ wastewater treatment, with a subsequent decrease under higher stress levels in both plant parts, i.e., leaves and roots. However, a $5.0 \mathrm{mM} \mathrm{CA}$ application significantly improved the APX activities of plants at all levels of wastewater treatment, as compared with those receiving no CA treatments.

\subsection{Chromium Concentration}

Concentration of $\mathrm{Cr}$ proportionally increased in sunflower root, stem, and leaves with the increasing wastewater concentration. Comparing with the control, the concentration of $\mathrm{Cr}$ in sunflower leaves increased by 97,171 , and 234 times, under $25 \%, 50 \%, 75 \%$, and $100 \%$ wastewater treatments, respectively. Application of $5.0 \mathrm{mM} \mathrm{CA}$ significantly increased $\mathrm{Cr}$ concentration in sunflower leaves under all stress levels, with a conspicuous rise (35\%) with the $100 \%$ wastewater treatment (Figure 6). The chromium concentration in the sunflower stem was increased by $92,132,179$, and 208 times, under $25 \%, 50 \%, 75 \%$, and $100 \%$ wastewater treatments, respectively. Exogenous CA application further increased the buildup of $\mathrm{Cr}$ in the sunflower stem under various concentrations of tannery wastewater. The maximum increase (36\%) in stem Cr concentration was detected under a $100 \%$ tannery wastewater treatment along with a $5.0 \mathrm{mMCA}$ application. 

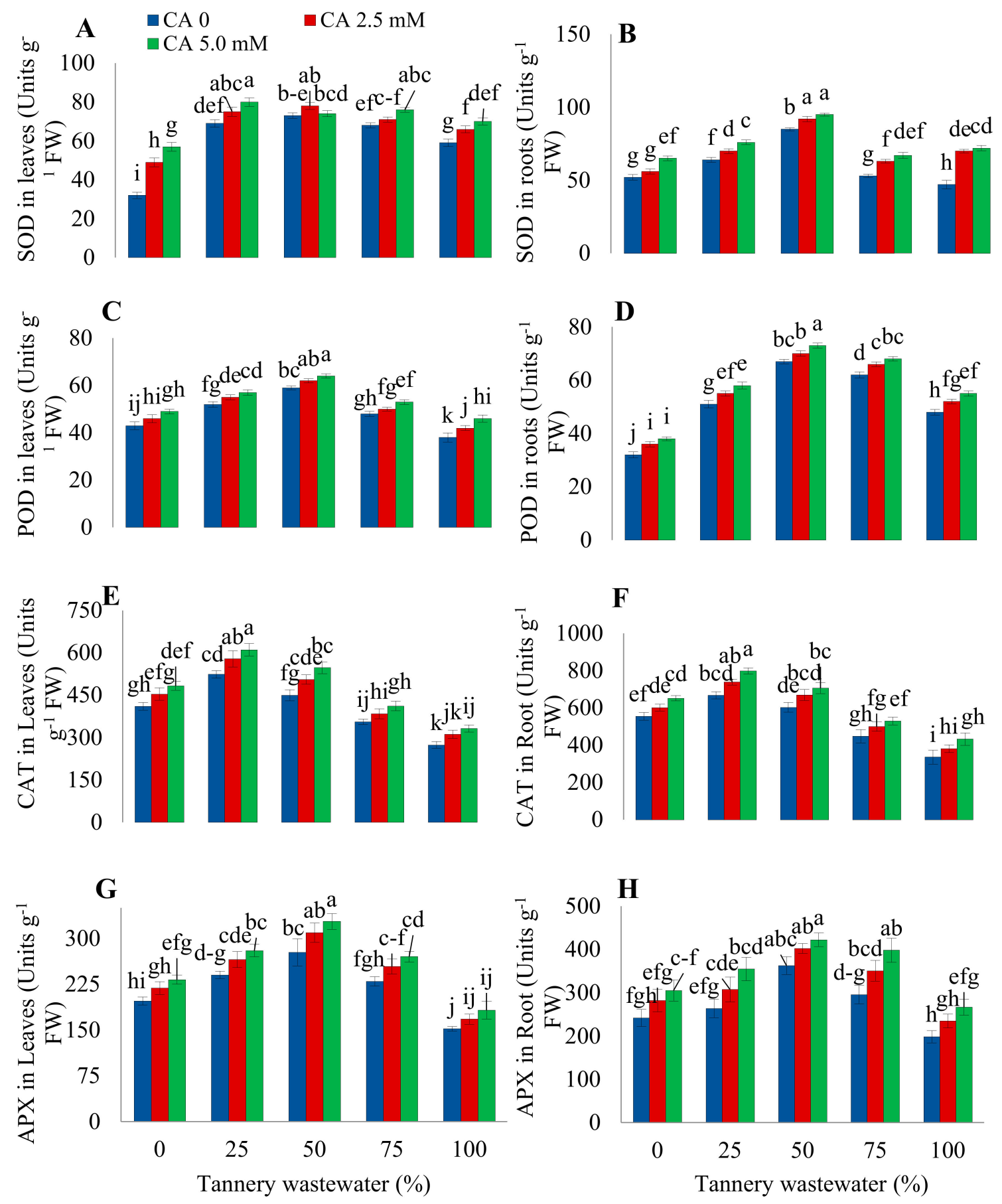

Figure 5. Impact of wastewater on and citric acid on leaf SOD (A), root SOD (B), leaf POD (C), root POD (D), leaf CAT (E), root CAT (F), leaf APX (G), and root APX (H) of sunflower plants. Data are means of 3 independent replicates, and different lettering indicates a significant difference among values at $p<0.05$.

Heavy metals primarily affected roots of the plants under stressful conditions. In this study, the roots of stressed plants revealed comparatively higher $\mathrm{Cr}$ concentrations than stems and leaves. In comparison with the control, root $\mathrm{Cr}$ concentration was increased by 113, 211, 308, and 377 times, under $25 \%, 50 \%, 75 \%$, and $100 \%$ wastewater treatments, respectively. Exogenously applied CA further increased the root $\mathrm{Cr}$ contents at all levels of wastewater application. The maximum value for $\mathrm{Cr}$ concentration in sunflower root was recorded with application of $5.0 \mathrm{mM} \mathrm{CA}$ with a $100 \%$ wastewater treatment. 


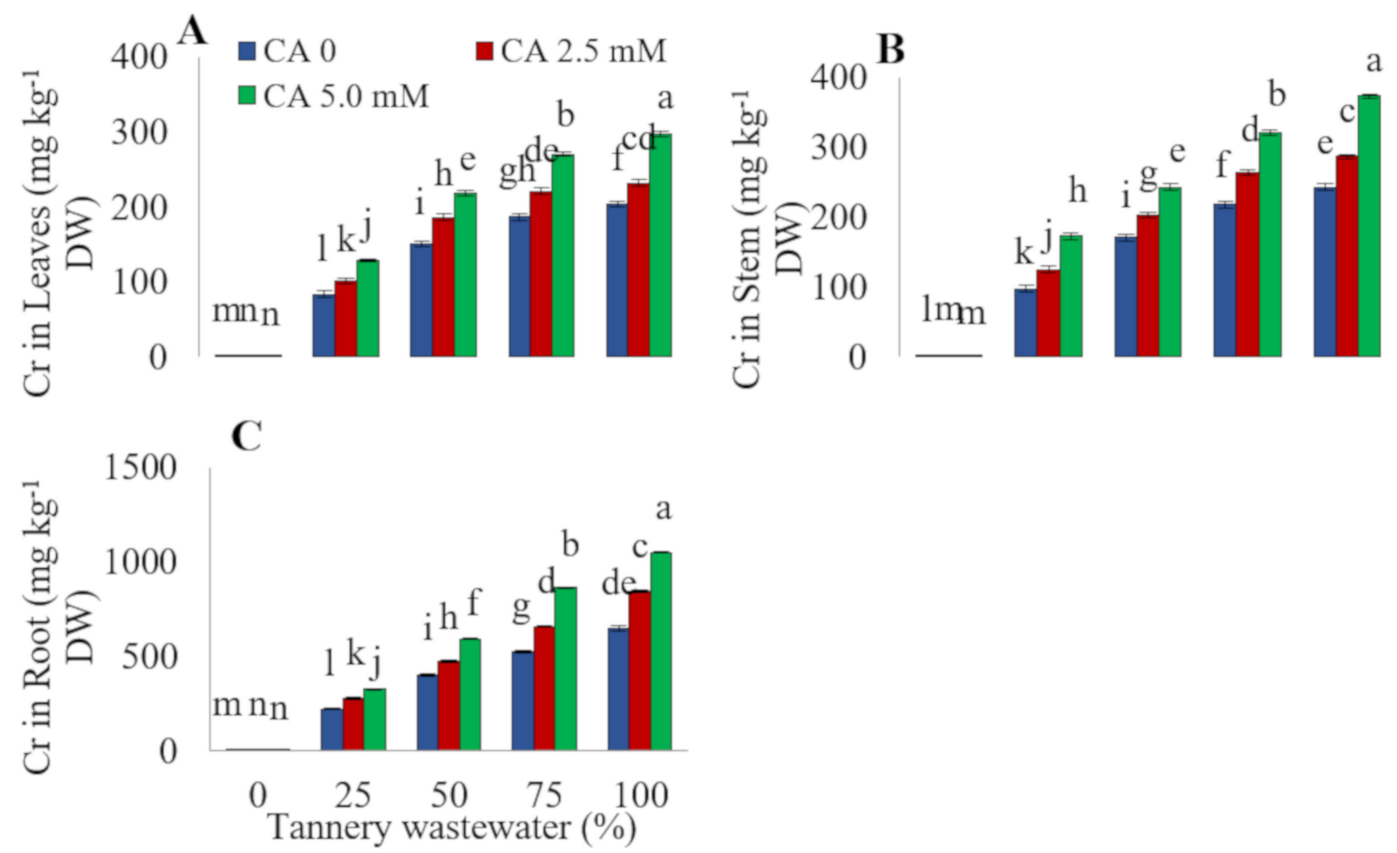

Figure 6. Impact of wastewater and citric acid on $\mathrm{Cr}$ concentration in leaves (A), stems (B), and roots (C) of sunflower plants. Data are means of 3 independent replicates and different lettering indicates a significant difference among the values at $p<0.05$.

\section{Discussion}

The present study elucidated the role of CA in mitigating the $\mathrm{Cr}$ toxicity caused by tannery wastewater in sunflower seedlings. Besides traces of several other heavy metals, tannery wastewater holds very high concentrations of $\mathrm{Cr}[2,20]$. Various morphological parameters of sunflowers, such as biomass, leaf area, number of leaves per plant, root length, and plant height considerably decreased with an increasing wastewater concentration (Figures 1 and 2), which may be attributed to the noxious amount of $\mathrm{Cr}$ in wastewater [20]. Previous reports have also revealed significant reductions in morphological features of various plant species under $\mathrm{Cr}$ toxicity $[11,20]$. Chromium induces morphological changes due to competition with other necessary nutrient elements, distortion of root and leaf ultrastructure, disruption in photosynthesis, and oxidative damage $[12,14,21]$. The findings of the current study are supported by the previous reports that $\mathrm{Cr}$ stress significantly decreased plant biomass, root length, and plant height in different plant species such as wheat, maize, tobacco, and spinach $[11,14,19,20]$. Citric acid treatment considerably improved the biomass and growth of stressed plants, in contrast to those irrigated with various wastewater concentrations without exogenous CA application (Figures 1 and 2). Improvement in the morphological characteristics of the plants might be attributed to the enhanced absorption of vital nutrients by sunflower plants [22].

It is a well-established fact that photosynthetic pigments perform a very crucial role in a plants' life due to their light harvesting function. Maqbool et al. [20] reported that $\mathrm{Cr}$ stress significantly affected the physiochemical attributes of the plants. In the current study, wastewater treatment prominently decreased the photosynthetic pigments in sunflower plants (Figure 3). Chlorophylls a, b, and total chlorophyll abruptly reduced with increasing tannery wastewater concentration. Reduction in plant growth may be attributed to the occurrence of high $\mathrm{Cr}$ concentrations in wastewater, which may have caused the structural impairment to chloroplast [11] and surplus generation of ROS under $\mathrm{Cr}$ induced stress [23]. Moreover, up-regulation of chlorophyllase under heavy metal stress constantly leads to an enormous reduction in chlorophyll pigments [24]. Citric acid application increased the chlorophyll contents in plants under tannery wastewater treatment. Similarly CA improved chlorophyll contents of wheat leaves under severe $\mathrm{Cr}$ toxicity [19]. Further, CA application also enhanced chlorophyll concentration in maize plants under drought condition [25]. Foliar application 
of CA caused an immense reduction in ROS generation and damage to the chloroplast, which resulted in an improvement in the pigment contents in plants [26].

Increased MDA content is an indication of membrane damage [27]. In the current study, $\mathrm{H}_{2} \mathrm{O}_{2}$, MDA contents, and EL, were considerably enhanced in plant root and leaves of sunflower plants irrigated with tannery wastewater (Figure 3). However, CA treatment markedly ameliorated the lipid peroxidation and membrane damage by scavenging the free radicals and reducing ROS production [19,25].

Antioxidant enzymes perform a very significant role in protecting the plants from oxidative stress. The present study showed enhancement in SOD, POD, CAT, and APX activities at slight to moderate stress levels. Increasing doses of wastewater drastically reduced POD and SOD activities, except POD activity in the leaves (Figure 4). Similar findings were also reported previously [28]. Mild levels of $\mathrm{Cr}$ stress increased antioxidant enzyme activities, whereas serious stress reduced maize antioxidant enzyme activities due to relentless oxidative injury [11]. This could be because $\mathrm{Cr}$ toxicity alarms the antioxidant machinery of plants into starting to scavenge the ROS. Nevertheless, higher Cr levels suppress the antioxidant system due to a continuous and increased production of ROS.

Increasing concentrations of tannery wastewater drastically increased $\mathrm{Cr}$ concentration in sunflower root, stems, and the leaves of sunflower plants (Figure 6). Roots exhibited a much higher amount of $\mathrm{Cr}$ as compared to stem and leaves of the sunflower. Similar results were observed in rice and oil-seed rapes [11,29]. This might be due to Cr immobilization by sugars as macromolecules [19], followed by compartmentalization in root cell vacuoles [30]. Exogenous application of CA promoted uptake and accumulation of $\mathrm{Cr}$ towards different plant parts under various levels of tannery wastewater (Figure 6). However, Ali et al. [19] observed that CA application significantly decreased the uptake of different metals and their translocations to upper parts of various plants. The CA-mediated restricted absorption of $\mathrm{Cr}$, due to the protection of the membrane system of plants, and resultant increase in the uptake of essential nutrients, might be the possible reason for enhanced plant growth [31]. Organic substances like fulvic acid and humic acid are well known for their constructive effects on heavy metals' mobility and bioavailability, because they formulate composite organo-metal complexes [32-34]. Citric acid might have made complexes with $\mathrm{Cr}$ ions, which could be among many different possible reasons for the increase in $\mathrm{Cr}$ uptake by sunflower [22].

Crops may also have the ability to reduce $\mathrm{Cr}^{6+}$ to $\mathrm{Cr}^{3+}$, which would likely to happen in roots with the help of $\mathrm{Cr}$ reductase enzymes, same as those present in bacteria for detoxification of heavy metals; however, such enzymes have not been identified in plants [35]. The effects of $\mathrm{Cr}$ on plants vary with growth medium as well as different $\mathrm{Cr}$ oxidation forms [36]. It is well reported that $\mathrm{Cr}$ (VI) has more toxic effects towards plants compared to $\mathrm{Cr}$ (III) [37]. Riaz et al. [36] reported that wheat growth was mainly regulated by a different oxidation form of $\mathrm{Cr}$ than that of the total $\mathrm{Cr}$.

\section{Materials and Methods}

\subsection{Experimental and Growth Conditions}

Experiments were run at Botanical Garden of the Government College University, Faisalabad. The seeds of sunflower plants (variety Hysun-33) were carefully surface sterilized with $3 \% \mathrm{H}_{2} \mathrm{O}_{2}$ for $20 \mathrm{~min}$, followed by washing cautiously with distilled water. Soil was air dried and sieved through a $2 \mathrm{~mm}$ strainer. After that, five seeds were sown in each pot filled with $8 \mathrm{~kg}$ of soil. After two weeks of germination, thinning was done and only two plants were kept in each pot. Prestudy soil analyses were performed according to the established protocols, as described in Table 1. Soil texture, sodium adsorption ratio (SAR), electrical conductivity (EC), soluble ions, and different trace elements were determined by Bouyoucos [38], Page et al. [39], US Salinity Lab. Staff [40], and Soltanpour [41], respectively. 
Table 1. The physicochemical characteristics of the soil used in the pot study.

\begin{tabular}{cc}
\hline Texture & Sandy Loam \\
\hline Silt & $15.0 \%$ \\
\hline Sand & $67.9 \%$ \\
\hline Clay & $17.10 \%$ \\
\hline EC & $1.96 \mathrm{dS} \mathrm{m}^{-1}$ \\
\hline $\mathrm{pH}$ & 7.61 \\
\hline SAR & $1.89\left(\mathrm{mmol} \mathrm{L}^{-1}\right)^{1 / 2}$ \\
\hline Available P $^{-1}$ & $2.11 \mathrm{mg} \mathrm{kg}^{-1}$ \\
\hline Organic matter $^{-1}$ & $2.51 \mathrm{mmol} \mathrm{L}^{-1}$ \\
\hline $\mathrm{HCO}_{3}{ }^{-1}$ & $11.44 \mathrm{mmol} \mathrm{L}^{-1}$ \\
\hline $\mathrm{SO}_{4}{ }^{-2}$ & $5.45 \mathrm{mmol} \mathrm{L}^{-1}$ \\
\hline $\mathrm{Cl}^{-}$ & $13.98 \mathrm{mmol} \mathrm{L}^{-1}$ \\
\hline $\mathrm{Ca}^{2+}+\mathrm{Mg}^{2+}$ & $0.04 \mathrm{mmol} \mathrm{L}^{-1}$ \\
\hline $\mathrm{K}^{+}$ & $5.23 \mathrm{mmol} \mathrm{L}^{-1}$ \\
\hline $\mathrm{Na}^{+}$ & $0.77 \mathrm{mg} \mathrm{kg}^{-1}$ \\
\hline Available Zn $^{2+}$ & $0.31 \mathrm{mg} \mathrm{kg}^{-1}$ \\
\hline Available Cu$^{2+}$ & $0.16 \mathrm{mg} \mathrm{kg}^{-1}$ \\
\hline Available Cr $^{2+}$ & \\
\hline
\end{tabular}

Here in Table 1, the EC stands for electrical conductivity and SAR stands for sodium adsorption ratio.

\subsection{Analysis of Tannery Wastewater and Application of Treatments}

Tannery wastewater was analyzed for various physicochemical characteristics through standard protocol [42] (Table 2). Two weeks old sunflower plants were irrigated every third day with five different levels $(0 \%, 25 \%, 50 \%, 75 \%$, and $100 \%)$ of tannery wastewater until harvesting. The number of pots were considered as one replicate per percentage of wastewater. After 1 week of the wastewater irrigation, the citric acid was sprayed at different concentrations $(0,2.5$ and $5.0 \mathrm{mM})$, with a 2-day interval, throughout the experiment. The plants in the control group were cautiously sprayed with the same quantity of distilled water. Chemical fertilizers were applied as described previously [19].

\subsection{Measurement of Morphological Attributes}

After 8 weeks of the 1st CA treatment, the plants were harvested. After harvesting, the plants were washed with distilled water and were carefully separated into stem, leaves, and roots. Data on various agronomic traits, such as plant height, root length, fresh and dry weight of roots and shoots, number of leaves per plant, and leaf area, were measured according to the standard procedures.

\subsection{Assessment of Oxidative Stress}

Oxidative stress was assessed by determining EL, MDA content, and $\mathrm{H}_{2} \mathrm{O}_{2}$ concentration, according to previously described methods [43-45].

\subsection{Photosynthetic Pigments and Antioxidant Enzyme Analysis}

The contents of chlorophyll $a, b$, and total chlorophyll were assessed by following established protocol [46]. Superoxide dismutase and POD activities were examined according to Zhang et al. [47]. Activities of CAT and APX were quantified by using the already developed protocol [48]. 
Table 2. Characteristics of tannery wastewater used for irrigation.

\begin{tabular}{cc}
\hline Parameters & Values \\
\hline COD & $2897 \mathrm{mg} \mathrm{L}^{-1}$ \\
\hline BOD & $876 \mathrm{mg} \mathrm{L}^{-1}$ \\
\hline TOC & $969 \mathrm{mg} \mathrm{L}^{-1}$ \\
\hline Oil \& grease & $11 \mathrm{mg} \mathrm{L}^{-1}$ \\
\hline $\mathrm{pH}$ & 4.13 \\
\hline $\mathrm{EC}$ & $91.8 \mathrm{dS} / \mathrm{m}$ \\
\hline TDS & 64,968 \\
\hline Total Cr & $329 \mathrm{mg} \mathrm{L}^{-1}$ \\
\hline $\mathrm{K}^{+}$ & $41 \mathrm{mg} \mathrm{L}^{-1}$ \\
\hline Carbonate $^{2+} \mathrm{ND}^{\mathrm{Ca}^{2+}+\mathrm{Mg}^{2+}}$ & $3.1 \mathrm{mmol}_{\mathrm{c}}{ }^{-1}$ \\
\hline
\end{tabular}

Here in Table 2, COD stands for chemical oxygen demand, BOD stands for biological oxygen demand, TOC stands for total organic compounds, EC stands for electrical conductivity, TDS stands for total dissolved solids, and ND stands for not detected.

\subsection{Determination of $\mathrm{Cr}$ Contents}

Plant samples were analyzed for $\mathrm{Cr}$ content in leaves, stems, and roots following the protocol described by Ehsan et al. [49]. Samples ( $0.5 \mathrm{~g})$ were ground into fine powder and burnt to ashes in a muffle furnace at $1000{ }^{\circ} \mathrm{C}$ for $12 \mathrm{~h}$, followed by acid digestion overnight. Afterwards, digested samples were filtered several times to get a clear extract. Finally, samples were analyzed by atomic absorption spectrophotometer (Halo DB-20/DB-20S, Dynamica Company, London, UK) and total Cr concentration was calculated by drawing standard curve.

\subsection{Statistical Analysis}

Complete randomized design was applied along with 3 replicates. Analysis of variance (ANOVA) was applied using statistical software (SPSS, version 23.0 for windows; IBM Corporation, Armonk, New York, U.S). A post hoc test followed by a Duncan test was applied to see significant difference among different treatments.

\section{Conclusions}

This study demonstrated that wastewater application reduced the morphological and photosynthetic attributes of plants. Substantial amount of total $\mathrm{Cr}$ accumulated in sunflower when provided with tannery wastewater. The CA application enhanced growth and photosynthetic pigments of sunflowers by decreasing the oxidative damage. Moreover, CA increased activities of antioxidant enzymes in sunflower plants. The total $\mathrm{Cr}$ uptake was enhanced with enhancing the concentration of CA. Current findings suggest that citric acid application could be an easy and effective strategy to alleviate chromium toxicity. However, further investigations should be done in the future on a molecular level with detailed mechanistic approaches in this regard.

Author Contributions: Conceptualization, A.I.M., S.A.S.C., A.I.H., M.R., A.H. (Afzal Hussain), S.A., E.F.A.A. and P.A. Data curation, A.I.M., A.I.H., M.R., S.A.H.B., A.H. (Afzal Hussain), Z.I.M., S.A., A.H. (Abeer Hashem) and P.A. Formal analysis, A.I.M., M.R., A.H. (Afzal Hussain), Z.I.M., S.A. and M.N.A Funding acquisition, A.I.H., M.R., A.H. (Afzal Hussain), A.H. (Abeer Hashem), E.F.A.A. and M.N.A. Investigation, S.A.S.C., A.I.H., S.A.H.B., Z.I.M., S.A. and A.H. (Abeer Hashem). Methodology, A.I.M., M.R., A.H. (Afzal Hussain), Z.I.M., M.N.A. and P.A. Project administration, A.I.M., M.R., S.A.H.B., A.H. (Afzal Hussain), E.F.A.A. and P.A. Resources, S.A.S.C., M.R., A.H. (Afzal Hussain), A.H. (Abeer Hashem), E.F.A.A., M.N.A. and P.A. Software, A.I.H. and A.H. (Afzal Hussain). Supervision, S.A.S.C. and S.A. Validation, A.I.H. Visualization, A.I.H. and S.A.H.B. Writing-original draft, A.I.M., 
S.A.H.B., A.H. (Afzal Hussain) and M.N.A. Writing-review and editing, S.A.S.C., A.I.H., M.R., S.A.H.B., A.H. (Afzal Hussain) and E.F.A.A. All authors have read and agreed to the published version of the manuscript.

Funding: Authors are also thankful to Government College University Faisalabad, Pakistan for the research support program, Project NO. 80-ENV.Sci-2. The authors would like to extend their sincere appreciation to the Researchers Supporting Project Number (RSP-2019/134), King Saud University, Riyadh, Saudi Arabia.

Acknowledgments: Authors are also thankful to Government College University Faisalabad, Pakistan for the research support program, Project NO. 80-ENV.Sci-2. The authors would like to extend their sincere appreciation to the Researchers Supporting Project Number (RSP-2019/134), King Saud University, Riyadh, Saudi Arabia.

Conflicts of Interest: The authors declare no conflicts of interest.

\section{References}

1. Qadir, A.; Malik, R.N.; Husain, S.Z. Spatio-temporal variations in water quality of Nullah Aik tributary of the river Chenab, Pakistan. Environ. Monit. Assess. 2008, 140, 43-59. [CrossRef]

2. Ashraf, S.; Afzal, M.; Rehman, K.; Naveed, M.; Zahir, Z.A. Plant-endophyte synergism in constructed wetlands enhances the remediation of tannery effluent. Water Sci. Technol. 2018, 77, 1262-1270. [CrossRef] [PubMed]

3. Khalid, S.; Shahid, M.; Dumat, C.; Niazi, N.K.; Bibi, I.; Gul Bakhat, H.F.S.; Abbas, G.; Murtaza, B.; Javeed, H.M.R. Influence of groundwater and wastewater irrigation on lead accumulation in soil and vegetables: Implications for health risk assessment and phytoremediation. Int. J. Phytoremediat. 2017, 19, 1037-1046. [CrossRef] [PubMed]

4. Rehman, M.Z.; Khalid, H.; Akmal, F.; Ali, S.; Rizwan, M.; Qayyum, M.F.; Iqbal, M.; Khalid, M.U.; Azhar, M. Effect of limestone, lignite and biochar applied alone and combined on cadmium uptake in wheat and rice under rotation in an effluent irrigated field. Environ. Pollut. 2017, 227, 560-568. [CrossRef] [PubMed]

5. Zaheer, I.E.; Ali, S.; Rizwan, M.; Abbas, Z.; Bukhari, S.A.H.; Wijaya, L.; Alyemeni, M.N.; Ahmad, P. Zinc-lysine prevents chromium-induced morphological, photosynthetic, and oxidative alterations in spinach irrigated with tannery wastewater. Environ. Sci. Pollut. Res. 2019, 26, 28951-28961. [CrossRef] [PubMed]

6. Khalil, U.; Shakoor, M.B.; Ali, S.; Rizwan, M. Tea waste as a potential biowaste for removal of hexavalent chromium from wastewater: Equilibrium and kinetic studies. Arab. J. Geosci. 2018, 11, 573. [CrossRef]

7. Oliveira, H. Chromium as an environmental pollutant: Insights on induced plant toxicity. J. Bot. 2012. [CrossRef]

8. Ali, S.; Rizwan, M.; Waqas, A.; Hussain, M.B.; Afzal, H.; Liu, S.; Alqarawi, A.A.; Hashem, A.; Abd Allah, E.F. Fulvic Acid Prevents Chromium-induced Morphological, Photosynthetic, and Oxidative Alterations in Wheat Irrigated with Tannery Waste Water. J. Plant Growth Regul. 2018, 37, 1357-1367. [CrossRef]

9. Habiba, U.; Ali, S.; Hafeez, F.; Rizwan, M.; Rehman, M.Z.; Hussain, A.; Asad, S.A. Morpho-physiological responses of maize cultivars exposed to chromium stress. Int. J. Agric. Biol. 2018, 21, 140-148.

10. Farid, M.; Ali, S.; Rizwan, M.; Ali, Q.; Saeed, R.; Nasire, T.; Abbasi, G.H.; Ishaq, M.; Rehmanig, A.; Karimh, S.T.A.; et al. Phytomanagement of chromium contaminated soils through sunflower under exogenously applied 5-aminolevulinic acid. Ecotoxicol. Environ. Saf. 2018, 151, 255-265. [CrossRef]

11. Gill, R.A.; Zang, L.; Ali, B.; Farooq, M.A.; Cui, P.; Yang, S.; Ali, S.; Zhou, W. Chromium-induced physio-chemical and ultrastructural changes in four cultivars of Brassica napus L. Chemosphere 2015, 120, 154-164. [CrossRef] [PubMed]

12. Ali, S.; Farooq, M.A.; Yasmeen, T.; Hussain, S.; Arif, M.S.; Abbas, F.; Bharwana, S.A.; Zhang, G. The influence of silicon on barley growth, photosynthesis and ultra-structure under chromium stress. Environ. Sci. Pollut. Res. 2013, 22, 10601-10609. [CrossRef] [PubMed]

13. Magenta, A.; Greco, S.; Gaetano, C.; Martelli, F. Oxidative stress and micrornas in vascular diseases. Int. J. Mol. Sci. 2013, 14, 17319-17346. [CrossRef]

14. Bukhari, S.A.H.; Wang, R.; Wang, W.; Ahmed, I.M.; Zheng, W.; Cao, F. Genotype-dependent effect of exogenous 24-epibrassinolide on chromium-induced changes in ultrastructure and physicochemical traits in tobacco seedlings. Environ. Sci. Pollut. Res. 2016, 23, 18229-18238. [CrossRef] [PubMed]

15. Schmidt, F.; Marnef, A.; Cheung, M.-K.; Wilson, I.; Hancock, J.; Staiger, D.; Ladomery, M. A proteomic analysis of oligo(dT)-bound mRNP containing oxidative stress-induced Arabidopsis thaliana RNA-binding proteins ATGRP7 and ATGRP8. Mol. Biol. Rep. 2010, 37, 839-845. [CrossRef] 
16. Rizwan, M.; Ali, S.; Qayyum, M.F.; Ok, Y.S.; Zia-ur-Rehman, M.; Abbas, Z.; Hannan, F. Use of maize (Zea mays L.) for phytomanagement of Cd-contaminated soils: A critical review. Environ. Geochem. Health 2016, 9, 259-277. [CrossRef] [PubMed]

17. Ondrasek, G.H.; Bakić, M.; Zovko, L.; Filipović, C.; Meriño-Gergichevich, R.; Savić, Z.; Rengel, Z. Biogeochemistry of soil organic matter in agroecosystems and environmental implications. Sci. Total Environ. 2019, 658, 1559-1573. [CrossRef]

18. Zaheer, I.E.; Ali, S.; Rizwan, M.; Farid, M.; Shakoor, M.B.; Gill, R.A.; Najeeb, U.; Iqbal, N.; Ahmad, R. Citric acid assisted phytoremediation of copper by Brassica napus L. Ecotoxicol. Environ. Saf. 2015, 120, 310-317. [CrossRef]

19. Ali, S.; Bharwana, S.A.; Rizwan, M.; Farid, M.; Kanwal, S.; Ali, Q.; Ibrahim, M.; Gill, R.A.; Khan, M.D. Fulvic acid mediates chromium (Cr) tolerance in wheat (Triticum aestivum L.) through lowering of $\mathrm{Cr}$ uptake and improved antioxidant defense system. Ecotoxicol. Environ. Saf. 2015, 89, 66-72. [CrossRef]

20. Maqbool, A.; Ali, S.; Rizwan, M.; Ishaque, W.; Rasool, N.; Rehman, M.Z.; Bashir, A.; Abid, M.; Wu, L. Management of tannery wastewater for improving growth attributes and reducing chromium uptake in spinach through citric acid application. Environ. Sci. Pollut. Res. 2018, 25, 10848-10856. [CrossRef]

21. Shakoor, M.B.; Ali, S.; Hameed, A.; Farid, M.; Hussain, S.; Yasmeen, T.; Najeeb, U.; Bharwana, S.A.; Abbasi, G.H. Citric acid improves lead $(\mathrm{Pb})$ phytoextraction in Brassica napus L. by mitigating Pb-induced morphological and biochemical damages. Ecotoxicol. Environ. Saf. 2014, 109, 38-47. [CrossRef] [PubMed]

22. Farid, M.; Ali, S.; Rizwan, M.; Ali, Q.; Abbas, F.; Bukhari, S.A.H.; Saeed, R.; Wu, L. Citric acid assisted phytoextraction of chromium by sunflower; morpho-physiological and biochemical alterations in plants. Ecotoxicol. Environ. Saf. 2017, 145, 90-102. [CrossRef] [PubMed]

23. Habiba, U.; Ali, S.; Farid, M.; Shakoor, M.B.; Rizwan, M.; Ibrahim, M.; Abbasi, G.H.; Hayat, T.; Ali, B. EDTA enhanced plant growth, antioxidant defense system, and phytoextraction of copper by Brassica napus L. Environ. Sci. Pollut. Res. 2015, 22, 1534-1544. [CrossRef] [PubMed]

24. Hegedüs, A.; Erdei, S.; Horváth, G. Comparative studies of $\mathrm{H} 2 \mathrm{O} 2$ detoxifying enzymes in green and greening barley seedlings under cadmium stress. Plant Sci. 2001, 160, 1085-1093. [CrossRef]

25. Anjum, N.A.; Ahmad, I.; Mohmood, I.; Pacheco, M.; Duarte, A.C.; Pereira, E.; Umar, S.; Ahmad, A.; Khan, N.A.; Iqbal, M.; et al. Modulation of glutathione and its related enzymes in plants' responses to toxic metals and metalloids-A review. Environ. Exp. Bot. 2012, 75, 307-324. [CrossRef]

26. Shahid, M.; Dumat, C.; Silvestre, J.; Pinelli, E. Effect of fulvic acids on lead-induced oxidative stress to metal sensitive Vicia faba L. plant. Biol. Fertil. Soils 2012, 48, 689-697. [CrossRef]

27. Schmid-Siegert, E.; Stepushenko, O.; Glauser, G.; Farmer, E.E. Membranes as structural antioxidants recycling of malondialdehyde to its source in oxidation-sensitive chloroplast fatty acids. J. Biol. Chem. 2016, 291, 13005-13013. [CrossRef]

28. Meng, H.; Hua, S.; Shamsi, I.H.; Jilani, G.; Li, Y.; Jiang, L. Cadmium-induced stress on the seed germination and seedling growth of Brassica napus L., and its alleviation through exogenous plant growth regulators. Plant Growth Regul. 2009, 58, 47-59. [CrossRef]

29. Zeng, F.; Qiu, B.; Ali, S.; Zhang, G. Genotypic differences in nutrient uptake and accumulation in rice under chromium stress. J. Plant Nutr. 2011, 33, 18-528. [CrossRef]

30. Kanwal, U.; Ali, S.; Shakoor, M.B.; Farid, M.; Hussain, S.; Yasmeen, T.; Adrees, M.; Bharwana, S.A.; Abbas, F. EDTA ameliorates phytoextraction of lead and plant growth by reducing morphological and biochemical injuries in Brassica napus L. under lead stress. Environ. Sci. Pollut. Res. 2014, 21, 9899-9910. [CrossRef]

31. Nardi, S.; Pizzeghello, D.; Muscolo, A.; Vianello, A. Physiological effects of humic substances in higher plants. Soil Biol. Biochem. 2002, 34, 1527-1537. [CrossRef]

32. Kang, J.; Zhang, Z.; Wang, J.J. Influence of humic substances on bio-availability of Cu and Zn during sewage sludge composting. Bioresour. Technol. 2011, 102, 8022-8026. [CrossRef] [PubMed]

33. Kwiatkowska-Malina, J. Qualitative and quantitative soil organic matter estimation for sustainable soil management. J. Soils Sediments 2018, 18, 2801-2812. [CrossRef]

34. Raptis, S.; Gasparatos, D.; Economou-Eliopoulos, M.; Petridis, A. Chromium uptake by lettuce as affected by the application of organic matter and $\mathrm{Cr}(\mathrm{VI})$-irrigation water: Implications to the land use and water management. Chemosphere 2018, 210, 597-606. [CrossRef] [PubMed]

35. Lytle, C.M.; Lytle, F.W.; Yang, N.; Qian, J.H.; Hansen, D.; Zayed, A.; Terry, N. Reduction of Cr (VI) to Cr (III) by wetland plants: Potential for in situ heavy metal detoxification. Environ. Sci. Technol. 1998, 32, 3087-3093. [CrossRef] 
36. Riaz, M.; Yasmeen, T.; Arif, M.S.; Ashraf, M.A.; Hussain, Q.; Shahzad, S.M.; Rizwan, M.; Mehmood, M.W.; Zia, A.; Mian, I.A.; et al. Variations in morphological and physiological traits of wheat regulated by chromium species in long-term tannery effluent irrigated soils. Chemosphere 2019, 222, 891-903. [CrossRef]

37. Gomes, M.A.D.C.; Hauser-Davis, R.A.; Suzuki, M.S.; Vitória, A.P. Plant chromium uptake and transport, physiological effects and recent advances in molecular investigations. Ecotoxicol. Environ. Saf. 2017, 140, 55-64. [CrossRef]

38. Ayers, R.S.; Westcot, D.W. Water quality for agriculture, pp. 95-97 Bouyoucos GJ (1962) Hydrometer method improved for making particle size analyses of soils. Agron. J. 1985, 54, 464-465.

39. Page, A.L.; Miller, R.H.; Keeny, D.R. Methods of soil analysis (Part 2). In Chemical and Microbiological Properties; Soil Science Society of America: Madison, WI, USA, 1982.

40. US Salinity Laboratory Staff. Diagnosis and improvement of saline and alkali soils. In Agriculture Handbook 60; United States Salinity Laboratory, US Department of Agriculture: Washington, DC, USA, 1954; p. 160.

41. Soltanpour, P.N. Use of AB-DTPA soil test to evaluate elemental availability and toxicity. Commun. Soil Sci. Plant Anal. 1985, 16, 323-338. [CrossRef]

42. Standard Methods for the Examination of Water and Wastewater; American Public Health Association: Washington, DC, USA, 2005; pp. 1-874.

43. Dionisio-Sese, M.L.; Tobita, S. Antioxidant responses of rice seedlings to salinity stress. Plant Sci. 1998, 135, 1-9. [CrossRef]

44. Dhindsa, R.A.; Plumb-Dhindsa, P.; Thorpe, T.A. Leaf senescence: Correlated with increased permeability and lipid peroxidation, and decreased levels of superoxide dismutase and catalase. J. Exp. Bot. 1981, 126, 93-101. [CrossRef]

45. Jana, S.; Choudhuri, M.A. Glycolate metabolism of three submerged aquatic angiosperms during aging. Aquat. Bot. 1981, 12, 345-354. [CrossRef]

46. Lichtenthaler, H.K. Chlorophylls and carotenoids-the pigments of photosynthetic biomembranes. In Methods in Enzymology; Colowick, S.P., Kaplan, N.O., Eds.; Academic Press: New York, NY, USA, 1987; Volume 148, pp. 350-382.

47. Zhang, J.; Cai, W.W.; Lee, D.J. Occupational hazards and pregnancy outcomes. Am. J. Ind. Med. 1992, 21, 397-408. [CrossRef] [PubMed]

48. Aebi, H. Catalasein vitro. Methods Enzymol. 1984, 105, 121-126.

49. Ehsan, S.; Ali, S.; Noureen, S.; Farid, M.; Shakoor, M.B.; Aslam, A.; Bharwana, S.A.; Tauqeer, H.M. Comparative assessment of different heavy metals in urban soil and vegetables irrigated with sewage/industrial waste water. Ecoterra 2013, 35, 37-53.

(C) 2020 by the authors. Licensee MDPI, Basel, Switzerland. This article is an open access article distributed under the terms and conditions of the Creative Commons Attribution (CC BY) license (http://creativecommons.org/licenses/by/4.0/). 